\title{
Regina Ganter
}

\section{The Contest for Aboriginal Souls. European Missionary Agendas in Australia}

Canberra: ANU Press and Aboriginal History Inc., 2018. $248+x$ pp. ISBN: 9781760462048. AUD 50.

Regina Ganter's book The Contest for Aboriginal Souls. European Missionary Agendas in Australia focuses on German-speaking missions and missionaries, their agendas and impact on Indigenous people. The author draws chiefly on primary source material in German that was not previously accessible in English. The book is furthermore a companion to the author's voluminous and detailed digital publication "German Missionaries in Australia - A Web-Directory of Intercultural Encounters". The major contribution of this book is the comparison of the patterns of different German-speaking missionaries and missions, the translations and thematic groupings of mission records, including analyses of interests that motivated settlers, governments, Indigenous people and individual missionaries.

In Australia, missionary writings were among the first records of contact and to date are making significant contributions to anthropology and ethnography as well as native title claims. The interest in missions has given rise to rather contradictory claims. On the one hand, missions aimed at civilising and assimilating Indigenous people, they assisted the erosion of traditional social structures, they confined Aboriginal people with paternalistic prohibitions and imprisonments and to date keep glossing over their sexual assaults. On the other hand, missions and missionaries are acknowledged as having protected the survival of Indigenous people and their languages against the violence of settler-colonialism, from blackbirding and mass murder. As Regina Ganter claims,

Under detailed historical investigation, all of these claims are true to some extent. In the process of this research, I have gained respect as well as empathy for the missionaries themselves, who were trained in theology to be thrown into forcefields of political manoeuvring; who came to look after souls and were left with the care of bodies. (xi, emphasis in original).

From the nineteenth century onwards, missions entered sites of conflict and settler violence. They struggled with problems of establishing sedentary communities, the much-needed supply of food and accommodation, while in the eyes of their funding bodies their success was judged solely by numbers of baptisms of Indigenous people. Throughout her book Regina Ganter elegantly navigates between these international geopolitical trends and Australian policies while also paying sufficient attention to individuals caught in between.

In Chapter 1, "The Quest for Ecclesiastical Territory - Catholics and Protestants", Ganter engages in the early competitive denominational efforts of missionaries in settler towns after the liberalising Church Act of 1836. The Catholic Church, rein- 
venting itself at that time, reached out to the world with new monastic societies and the inclusion of laity in evangelising mission. At the time, The Society of the Catholic Apostolate (also known as the Pallottines) and the Missionaries of the Sacred Heart became particularly active in the Kimberley and the Northern Territory. They created a solid Catholic institutional presence for decades to come. Furthermore, two groups of German Protestant missionaries arrived in the Moreton Bay region and South Australia. The Zion Hill Mission and the Dresden Mission Society were expected to form the 'Moravian model'. Thus, from the beginning, there was territorial competition, between Benedictines and other Catholics; between Catholics and Protestants, among Protestants themselves, and between English-speaking and German-speaking missions (22).

Chapter 2, "Protestants Divided", presents further detail on how different German confessional orientations and missionary training colleges resulted in tensions in the missions. Splintering mission efforts were influenced by confessional disputes and personal clashes rather than a common purpose. (A united Lutheran church in Australia was formed in 1966.)

Chapter 3, "Empires of Faith", then highlights the relevance of missions as strategic stepping-stones into further territories. It engages in the late nineteenth century colonial acquisitions worldwide and the following competitive increase in missions that lasted through World War I and II. Interestingly, upon carving further into the ecclesiastical territory of northern Australia, Christian missionaries met the so far unacknowledged fact that Indigenous people were already exposed to monotheistic beliefs. Islam had been brought in through trade routes since the seventh century. Likewise, spheres of religious influence had to be renegotiated also in the northwest during the prime of the pearling industry, as it attracted more Asian workers.

With the anti-German sentiment growing during World War I, many families and even townships had to anglicise their names (64). German missions were under major reorganisation to accommodate the concerns of military intelligence. During World War II the whole north was designated a strategically sensitive region (70).

The subsequent end of the mission period coincided with the changing Zeitgeist and growing postcolonial movements around the world (72). "There were the citizen aspirations of an increasingly mixed and educated Indigenous population who no longer fitted into the protective mission paradigm" (74). Government's assimilation policy was "clawing back control over Aboriginal people from the churches" by sending their own teachers to the missions (74-75). And there was the renewal within the churches themselves (74).

After these historical insights into the rise and fall of German missions in Australia, Chapter 4, "The Subtle Ontology of Power", turns towards a number of curious factors that facilitated the Christian contest for Aboriginal souls. In contrast to other settlers, missionaries openly engaged with the supernatural and offered "new ways of harnessing and directing preternatural forces" (81). As Ganter notices, "prayer, blessings and worship, with altar boys and priests dressed for a carefully orchestrated ceremony, were easily intelligible to peoples already used to staged rituals and incantations in an attempt to influence the supramaterial world" (81). Missionaries were respected for the power over the non-material world, for the written information from which their knowledge arose, and for the impressive arsenal of rituals and related objects (81). Moreover, missionaries could sometimes heal (e.g., 
use smallpox vaccine, snake oil, blessed water), they obeyed food taboos, used icons inscribed with spiritual powers, and appealed to the spirit world to achieve desired outcomes (96). God's ability to punish also echoed with Indigenous practices of distance killings (97). The missionary convention of referring to each other by symbolic kinship terms (Father, Brother, Sister, Mother) also fitted well with Indigenous expectations of the assimilation of strangers $(82,88)$. Baptism was a public ritual revolving around the bestowal of a name to signify belonging and relationship with the family of Christ, which was a new world of meaning and influence that devalued age as a marker of respect.

However, the establishment of relationships between missionaries and Indigenous people did not go smoothly. Polygamy was one of the major impediments to adult baptism and one of many ways in which missionary marriage rules deeply disturbed Indigenous social relationships (93-94). Another object of serious reflection to some Aboriginal people was the image of Jesus nailed to the cross: Would it be the way they will be punished as well (97-98)? This fear was not easily reconciled with the message of Jesus' love and the image of a potentially vengeful God (98). Along these lines, Ganter also presents several stories, when the signs of divine providence were used to impress Indigenous people with the strength of the superior force. However, she equally shows how Catholic missionaries, for example, conveniently ignored signs that told them to abandon their plans for missions, such as fever and diarrhoea, getting bogged in a swamp, encounters with snakes or even the monster-birth of a one-eyed goat.

Such "cultural double binds" (especially of burying and marrying traditions) complicated the lives of all mission residents. Missionaries could punish Aboriginal people if they followed traditional obligations, while not meeting such expectations could end in a punishment from the elders (98-99), another reason for why missionaries struggled to recruit Indigenous intermediaries.

Chapter 5, "Engaging with Missionaries", presents these often-ignored local intermediaries in detail. It addresses several anecdotal misunderstandings between missionaries and Indigenous people, especially when missionaries' teachings and their assumptions of cultural superiority were questioned.

Thus, and despite the many resonances of Christian teachings and rituals with Aboriginal cultural practices (discussed in Chapter 4), a middle ground was rarely created. Rather, Indigenous people often felt that "Jesus was always on the team of the white people" (119). Some missions were successful to have a native evangelist who helped convey interpretations across language and cultural barriers. One of the key cultural intermediaries in the Kimberley, for example, was the Aboriginal-Filipino Catholic family of Agnes and Thomas Puertollano. Their story highlights how Filipino lay helpers were instrumental in the establishment of relationships between the mission and Indigenous society, and also of how the discriminating policies of the state government problematized their efforts.

Chapter 6, "The Trials of Missionary Life", then takes a closer look at missionaries themselves. Who accepted the call into mission service and what were their motivations? "The lure of adventure was surely a factor in recruiting young men into denominational development aid" (147). Mission publications, newsletters and autobiographies, exoticized the encounter with foreign worlds, the outback and Aboriginality. The everyday life of missionaries, on the other hand, was not a com- 
fortable adventure. "The remote mission workers had to rely on each other for economic, social and emotional support" (158). They faced tropical diseases, deaths of their spouses or children, natural disasters, lack of privacy, social isolation and short supplies of virtually everything. Under such circumstances, "faith needs, after all, to be taken seriously if we wish to understand what powered the mission movement" (169).

Finally, in Chapter 7, "The German Differences", Ganter engages with the 'German flavour' of missions supervised by Germans (176). From German festivities (e.g. St. Martin) and popular hymns to the preparations of specific foods (e.g. Sauerkraut, Mettwurst or Lebkuchen) to the layout of missions in resemblance of German rural villages. Rather than learning English, German missionaries acquired local languages. Here Ganter points to differences in English and German intellectual traditions and underlying approaches to distant cultures (functionalist evolutionary thought vs. the interactionist Kulturkreis approach), which also facilitated differing approaches to Aboriginal people (188-191).

Meanwhile, physical punishment is one of the most accentuated criticisms for German missionaries. Ingrained in the idea of the German upbringing, it became an extension of colonial violence and was an expression of new hierarchy and authority (193-194). Which is why, "it seems difficult to fashion a reconciliatory mission history that takes into honest account the intentions, processes and outcomes at play" (211), also in the light of the dysfunctions of missions (e.g. child abuse, sexual misdemeanour).

Regina Ganter has done an incredibly meticulous (and often detective) work in sorting through a massive amount of detailed records of German-speaking missionaries. This book has its clear aim - the focus on German missionaries in Australia - and it attends to it. The Contest for Aboriginal Souls makes a significant contribution to studies in Australian history, Aboriginal culture, anthropology, Christian missions, and European colonialism. Together with the recently released edited volume - Peterson and Kenny's "German Ethnography in Australia"1 - Regina Ganter's book is a timely addition to the gradual translations of recorded Australian history left in German. 